\title{
Analysis of the Application of Case Mining in the Curriculum Ideological and Political Education Taking Macroeconomics as an Example
}

\author{
Jing Cang ${ }^{1, *}$ Fang Liu $^{2}$ \\ ${ }^{1}$ School of economics, Shandong Technology and Business University, Yantai, Shandong 264005, China \\ ${ }^{2}$ Office of Internal Audit, Shandong Technology and Business University, Yantai, Shandong 264005, China \\ *Corresponding author. Email: 2993933693@qq.com
}

\begin{abstract}
Curriculum ideological and political education has become a normal mechanism and concept of higher education in China, which requires teachers to constantly explore the ways and approaches of ideological and political education. The explanation of the "economic miracle" during the 40 years of China's reform and opening up and the practice of China's fiscal policy during the 13th Five-Year Plan period are taken as examples in the paper to elaborate the mining of cases concerning ideological and political education in macroeconomics, the goal and teaching feedback of ideological and political education, the types of ideological and political education cases and the ways to choose. The purpose of this paper is to convey and interpret China's economic growth and development practices, such as Chinese path, Chinese story, Chinese wisdom and Chinese approach, through cases concerning ideological and political education, so as to enhance students' confidence in culture, path and social responsibility.
\end{abstract}

Keywords: Curriculum ideological and political education, Case mining, Macroeconomics

\section{INTRODUCTION}

Guidelines for Curriculum Ideological and Political Education Construction of Institution of Higher Learning issued by the Ministry of Education in 2020 requires indepth exploration of ideological and political education resources contained in all kinds of courses and teaching methods, and innovation of educational and teaching methods, to help students establish favorable outlook on world, life and values in knowledge learning and ability cultivation [1]. Among them, "socialism with Chinese characteristics and the Chinese dream education, socialist core values education, the rule of law education, labor education, mental health education, excellent Chinese traditional culture education" dominate[2]. Macroeconomics, a professional basic course for business majors in Chinese colleges and universities, has a theoretical background mainly based on the economic system and policy practice of western developed countries. Most textbooks (including those compiled in China) also discuss with the cases and data of these countries. The excavation of cases concerning ideological and political education from China's economic practice and policy in the teaching process and the realization of educational function of the course require search for representative and professional case materials. The abundance of research literature and materials on economic issues in China facilitates the selection of appropriate academic research cases and policy practice cases, which is a feasible and efficient way integrating economic theory and practice with ideological and political education.

\section{AN EXPLANATION OF CHINA'S ECONOMIC MIRACLE IN THE PAST 40 YEARS OF REFORM AND OPENING UP}

\subsection{Case Description}

From reform and opening-up in 1978 to 2018, China's economy achieved an average annual GDP growth of 9.5 percent for 40 consecutive years, which is known as the "China Miracle". Explanations of the "China Miracle" can be found in a variety of books and related literature, among which the nearly million-word "Medium and Long-term Development and Transformation of the Chinese Economy: an International Perspective", led by Nobel Laureate Professor Michael Spence, is a 
representative. Five reasons are concluded in the book: 1 . making the most of the world economy; 2 . maintaining the stability of the macro economy; 3 . maintaining a high savings rate and investment rate; 4 . allocating resources through the market; 5 . a responsible, credible and capable government[3][4].

The five successful experiences of China over the past decades are regarded as valuable lessons for other countries to refer to. The last one is obviously contrary to the mainstream of modern western economics, and it is also an impossible element in the theoretical modeling of growth and development of mainstream modern economics.

In addition, Liu He, a famous Chinese economist and now Vice Premier of the State Council, once credited the "China miracle" to six reasons:

1. Consensus on development formed based on the reflection of the cultural revolution; 2. Unswervingly opening up to the outside world and joining the division of labor and the market system in the financial industry; 3. Adhering to the direction of market-oriented reform; 4. Maintaining political stability and giving play to institutional advantages; 5. Making full use of various comparative advantages of the country; 6. Cultural deposits play a gradually increasing supporting role [3].

Of course, the understanding of the "China miracle" economic phenomenon must be much more than the above mentioned. However, in terms of these two views, some scholars believe that they are experience rather than theory, let alone innovation of new knowledge concepts and ideological systems. Based on the analytical framework of predecessors, they describe the concrete reasons for China's miracle. In addition, empirical analysis involves but is not limited to economics or the field of economics. Spence's fifth point emphasizes the role of government. Except for the second and third points on economy, Liu He expounded the importance of economic growth from the aspects of politics, society, government and culture.

\subsection{Case Review}

\subsubsection{Ideological Elements}

Economic growth serves as both one of the main contents of macroeconomics and one of the most widely concerned topics of governments, economists, sociologists, and the public. With the increasing population, the survival and development of human beings, social progress and civilization require more material products. As for countries, especially developing countries, sustained and stable economic growth can provide better well-being for the residents.

What exactly determines economic growth? Western economics believes that there are direct and fundamental reasons. The former is the traditional four elements of economic growth: human capital, natural resources, material capital, and technological progress; the latter includes institutions, culture, and geography, which drive the function of direct reasons.

Interpretation of the "China miracle" varies from person to person. There are theoretical explorations, experience summaries, and cultural and policy analysis. If the theory of mainstream economics is employed to explain economic growth, factors such as government, culture, and national characteristics are excluded. However, they serve as fundamental reasons. Therefore, western mainstream economics is not universal. Macroeconomics theory should not be used blindly to interpret economic reality, explain macroeconomic policies, explain economic problems, especially to interpret China's economic practice. The historical process, cultural characteristics, national characteristics, Chinese history, cultural background and development context should be taken into full consideration when studying and researching macroeconomics. Multiperspectives, multi-levels and multi-disciplines should be integrated to avoid the linear thinking of western economics which is modeled, structured and mathematically. Therefore, in addition to mastering the basic principles of Western macroeconomics, Chinese elements such as Chinese model, Chinese path, Chinese solution, Chinese story, Chinese wisdom and so on should be integrated into the curriculum. On the basis of China's economic practice, western macroeconomic theories should be treated with an open, inclusive, cautious and dialectical attitude. Since theory comes from practice, a good grasp of universality and particularity is more conducive to understanding the real world and the causal relationship behind the phenomenon, so is the study of western economics.

\subsubsection{Teaching Goals of Ideological and Political Education}

Through the interpretation of "China's economic miracle", students studying western macroeconomics are expected to consider China's national conditions, Chinese history and Chinese culture, pay close attention to economic situation and understand macroeconomic policies. They should also go deep into the society, read more books, think more and pay attention to practical problems so as to enhance their cultural confidence and patriotism and cultivate their ability to analyse problems. Secondly, students should realize the advantages and limitations of western macroeconomics theories, and strengthen their understanding of "Sinicization and Times" of macroeconomics. Thirdly, students are motivated to compare the macroeconomic thinking of ancient Chinese sages such as Guan Zhong, and the theoretical explorations and innovations of contemporary Chinese economists, so as to understand that China's 
economic practice with 1.4 billion population will contribute vast and valuable Chinese material to the theoretical innovation, experience summary and policy analysis of macroeconomics.

\subsubsection{Teaching Effect and Enlightenment of Ideological and Political Education}

The case study was very rewarding for the students. Students realized that many factors, such as China's socialist economic system, the government's macrocontrol and the original intention of ruling for the people, the cultural and national characteristics of living and working in peace and contentment and getting rich through hard work, are the fundamental reasons for the sustained and stable economic growth, which enhanced their confidence in the theory, path, system and culture of China's socialist system, and their sense of social responsibility. The contribution of revealing the fundamental problems or essential causes behind economic phenomena to cultivating and improving the ability to analyse problems is also recognized. Secondly, the combination of this case and the principles of macroeconomics makes students realize that several key points should be grasped when combining theory with practical problems: First, the social system and cultural differences between China and foreign countries; The second is to distinguish between phenomena and problems; Third, looking at problems dialectically from the perspective of development is conducive to establishing a correct outlook on life, world outlook and values.

\section{PRACTICE OF CHINA'S FISCAL POLICY DURING THE 13TH FIVE-YEAR PLAN PERIOD}

\section{1. Case Description}

Since the 13th Five-Year Plan (2016-2020), China has focused on supply-side structural reform, implemented proactive fiscal policies more effectively, played a bigger role in expanding domestic demand and adjusting the structure, effectively ensured and improved people's livelihood, and vigorously promoted sustained and sound economic and social development. It is specifically shown in [5]:

The first is to step up efforts to cut taxes and fees to effectively ease the burden on the real economy.

Statistics show that from 2016 to 2019, additional tax cuts and fees will amount to about 570 billion yuan, 1 trillion yuan, 1.3 trillion yuan and 2.36 trillion yuan respectively, and an additional 2.5 trillion yuan is expected this year.

The second is to deepen supply-side structural reform to promote high-quality economic development.
Since the "13th Five-Year Plan", the proactive fiscal policy has been implemented, the supply-side structural reform has been adhering to, more reform methods have been adopted, more marketization and rule of law have been used, and efforts have been made to "consolidate, strengthen, enhance and unimpeded", so as to enhance the quality advantage of China's economy.

The third is to maintain the necessary scale of fiscal spending to support the expansion of domestic demand.

From 2016 to 2019, the national government deficit increased from 2.18 trillion yuan to 2.76 trillion yuan, and this year it will be further increased to 3.76 trillion yuan to respond to the impact of the epidemic. By coordinating fiscal revenue, deficits, and invoking budget stabilization funds, fiscal expenditures increased from 14 trillion yuan in 2013 to 23.9 trillion yuan in 2019 , an average annual increase of $9.6 \%$, higher than the average annual growth rate of fiscal revenue during the same period of 2.4 percentage points. In this year's budget, government spending is set at 24.8 trillion yuan, which will remain at a relatively high level.

The fourth is to strengthen policy guarantees and financial support to resolutely win the three critical battles (risk management, poverty reduction and pollution control).

By the end of 2019, the outstanding debt of local governments stood at 21.31 trillion yuan, and the debt ratio of local governments was 82.9 percent, lower than the international warning line of 100 percent to 120 percent. The risks were generally under control. The current poverty alleviation standards were upheld, the funding and policy systems were improved, and all efforts were made to support winning the crucial battle against poverty. Trials for clean heating in northern cities were implemented, and strong support was given to key projects such as ecological protection and restoration of the Yangtze Economic Belt and the remediation and treatment of contaminated soil, thus promoting continuous improvement of ecological and environmental quality.

The fifth is to endeavour to ensure and improve people's wellbeing.

From 2016 to 2019 , the total expenditure on key areas related to people's livelihood, such as education, social security and employment, urban and rural communities, medical and health care, family planning, housing security, energy conservation, environmental protection, culture, sports, and the media, increased from 9.6 trillion yuan to 12.4 trillion yuan, or 52.1 percent of the total expenditure from 51.1 percent. 


\subsection{Case Review}

\subsubsection{Ideological Elements}

Fiscal policy is an important part of macroeconomics curriculum, and also one of the main policies of governments to intervene in macroeconomics, which has attracted the attention of economists and the public. The year 2020 is an extraordinary year. It is also the final year of China's 13th Five-Year Plan. During the 13th FiveYear Plan period, China's fiscal policies have made great contributions to reducing the burden on the real economy, activating economic potential, promoting high-quality economic development, expanding domestic demand, preventing and defusing major risks, targeting poverty alleviation, preventing and controlling pollution, improving and ensuring people's livelihood, effectively preventing and controlling the epidemic, and resuming work and production. The concept of people-centered development has been highlighted, profoundly revealing the need for the government to better play its role under the conditions of the socialist market economy.

The practice of proactive fiscal policy during the "13th Five-Year Plan" in China further proves that: (1) the fundamental purpose of macro-control in China is different from that of western developed countries. China's proactive fiscal policy has always taken ensuring and improving people's living standards as the primary and ultimate goal, adhered to the philosophy of peoplecentered development and put the people first, and highlighted the public nature and fairness of public finance so that the fruits of reform and development will benefit the people in a more equitable way. This is determined by the nature of China's socialist system. At a higher level, the goal of China's proactive fiscal policy is to make the macroeconomic operation more stable, continuously develop the productive forces, and strive to address the contradiction between the people's evergrowing needs for a better life and unbalanced and inadequate development. (2) China's macro-control system is more comprehensive and diversified. Traditional macroeconomic policies of western economics focus on the short term and are limited to aggregate demand management. China's macro-control system not only emphasizes aggregate balance and structural coordination between the demand and supply sides, but also gives consideration to the unity of longterm and short-term goals. It is characterized by continuity, stability and sustainability, and is more forward-looking and flexible. Supply and demand are the two basic aspects of the internal relationship of market economy, which is a dialectical relationship of unity of opposites. Supply side management and demand side management are naturally the two starting points of macro-control economy. The former emphasizes structural issues, focusing on the long term and stimulating economic growth. The latter emphasizes the overall problem, focusing on short-term regulation and maintaining economic stability [6]. (3) The leading idea of macro-control in China is to ensure that the market plays a decisive role in the allocation of resources, and how to better play the role of the government. Under the socialist market economy system in China, the main duties and functions of the government are to maintain market order, ensure fair competition, maintain macroeconomic stability, strengthen and optimize public services, promote sustainable development, and promote common prosperity. The roles of the market and the government are organic and unified, rather than negating, separating and opposing each other.

\subsection{Teaching Goals of Ideological and Political Education}

By understanding the contents and objectives of China's fiscal policies during the 13th Five-Year Plan period, students' perceptual understanding of macroeconomics can be strengthened. The data and specific measures in the case are helpful for students to deepen their cognition of China's fiscal policy, realize the harmonious and complementary relationship between the government and the market in the socialist market economy with Chinese characteristics, and understand the connotation and essence of the government's proactive fiscal policy. Students can be guided to learn more about the practice of macroeconomic policies in the course study, be good at catching and facing problems, and enhance the ability of combining theory with practice. In addition, students recognize the continuity of China's macroeconomic policies, and abide by the core principles of people-centered, taking from the people for the people, fairness and justice, and common prosperity, so as to strengthen the concept of treating, understanding and applying the basic principles of macroeconomics dialectically from China's economic practice.

\subsection{Teaching Effect and Enlightenment of Ideological and Political Education}

This case made the students realize the rich content of the concrete practice of China's fiscal policy and the positive policy orientation, and deepened their understanding of "what is the positive fiscal policy". The essential difference between China's supply-side structural reform and the total supply management of western macroeconomics or the proposition of supplyside school is made clear. The basic structure of China's fiscal revenue and expenditure and its changes can be understood, and the financial support required by the new development concept of "innovation, coordination, green, opening up and sharing" can be initially qualitatively and quantitatively understood. Every coin has two sides, and the macroeconomic policy in western economics is no exception. So far, there is still no broad consensus on macroeconomic theory and policy. For example, the 
effectiveness of macroeconomic policies to stabilize the economy, the advantages and disadvantages of government fiscal deficit policies, and so on, have been debated. The challenge is to make sense of these arguments and disagreements. However, ideological and political education should always follow the basic starting point and principles of China's socialist system and economic practice, such as protecting the interests of the people, practice tries truth, common prosperity, concrete analysis of specific problems, theory comes from practice, so as to deal with various problems, which is also a criterion for the implementation of ideological and political education curriculum.

\section{CONCLUSION}

With the continuous deepening and implementation of the Ministry of Education's comprehensive promotion of the curriculum ideological and political construction of colleges and universities, the responsibility and goal of talent training in colleges and universities have been endowed with new connotations, which requires all teachers in colleges and universities to participate in the construction of ideological and political education of the curriculum, take up the responsibility of ideological and political education of the curriculum, keep learning, practice and comprehensive understanding. Macroeconomics courses from western countries also need to be constantly adapted to economic practices related to the realization of the "China Dream", and new ideological and political elements will naturally come into being in this process. China's rich economic practice (including theory, experience, policy, etc.) is a rich mine of curriculum ideological and political education cases, which needs to be excavated and sorted out. Cases (or materials) are classified into theory and experience, policy analysis and statistical reports, etc., which are available in academic resource databases such as CNKI, published works on the Chinese economy, official WeChat official accounts of various government departments such as the Ministry of Finance, official website of the National Bureau of Statistics, and platforms such as Learning Power. Of course, the selection of cases is very important, as it should not only reflect basic economic principles, but also integrate ideological and political elements such as core values of socialism with Chinese characteristics and excellent traditional culture. Teachers are required to follow the national development strategy closely on the basis of reading a lot of existing literature, with a diligent attitude, and deeply study and understand the spirit of the "14th Five-Year Plan" and other national medium and longterm vision goals, so as to excavate and select the appropriate case materials. Students can also be motivated to participate autonomously in groups and other ways. While improving their autonomous learning ability, they will naturally realize self-education in ideological and political courses and cultivate team spirit, which can better implement the fundamental task of cultivating people by virtue and cultivate college students who are well developed morally, intellectually, physically and aesthetically.

\section{AUTHORS' CONTRIBUTIONS}

Jing Cang is responsible for the structural design and wrote the manuscript, Fang Liu contributed to revising and editing for the paper in Authors' Contributions.

\section{REFERENCES}

[1] Liu Fujun. On the Connotation and Elements of Curriculum Ideological and Political Education [J]. The Guide of Science \& Education, 2020.10 (Midday Issue) 33-34. (in Chinese)

[2] Wan Yufeng, Liang Dan. constructing the educational pattern of all staff, whole process and all-round education -- The Ministry of Education promotes the ideological and political construction of college curriculum in an all-round way $[\mathrm{N}]$. China Education News, 2020-06-06 (01). (in Chinese)

[3] Xia Bin. "China's Miracle": Reflections on Theoretic Innovations by an Economist. China Chief Economist Forum, 2019.3.19. (in Chinese)

[4] Translated by Yu Jiang et al., edited by Michael Spencer, Medium and Long-term Development and Transformation of the Chinese Economy: an International Perspective" [M]. Intellectual Property Publishing House Co., Ltd., 2020.1. (in Chinese)

[5] WeChat official account of The Ministry of Finance, 2020.10.12. (in Chinese)

[6] Writing Group of "Western Economics". "Western Economics" (Second Edition) Volume 2 [M]. Higher Education Press, 2019.9.246-247. (in Chinese) 